\title{
KELEKATAN IBU-ANAK, PERTUMBUHAN ANAK, DAN PERKEMBANGAN SOSIAL EMOSI ANAK USIA PRASEKOLAH
}

\author{
Ani Wijirahayu ${ }^{1 *}$, Diah Krisnatuti ${ }^{2}$, Istiqlaliyah Muflikhati ${ }^{2}$ \\ 1 Program Studi IImu Keluarga dan Perkembangan Anak, Sekolah Pascasarjana, Institut Pertanian Bogor, Bogor \\ 16680, Indonesia \\ 2 Departemen Ilmu Keluarga dan Konsumen, Fakultas Ekologi Manusia, Institut Pertanian Bogor, Bogor 16680, \\ Indonesia \\ *) Email: annirahayu96@gmail.com
}

\begin{abstract}
Abstrak
Tujuan penelitian ini adalah untuk menganalisis pengaruh kelekatan ibu-anak dan pertumbuhan anak terhadap perkembangan sosial emosi anak usia prasekolah. Penelitian ini menggunakan desain cross sectional study dan dilakukan di Kelurahan Balumbang Jaya, Kecamatan Bogor Barat, Kota Bogor.. Seratus keluarga dipilih secara purposive sampling di lokasi penelitian dengan syarat mempunyai anak usia prasekolah; dan selanjutnya ibu dilibatkan sebagai responden dalam penelitian ini. Untuk menjawab tujuan penelitian, data dianalisis menggunakan regresi linear berganda. Penelitian ini menunjukkan bahwa tiga dari lima ibu $(61,0 \%)$ memiliki kelekatan ibu-anak terkategori tidak aman (insecure). Selain itu, sekitar 7 dari 10 anak $(70,0 \%)$ mengalami risiko gangguan pertumbuhan. Perkembangan sosial emosi anak terkategori sedang dengan indeks rataan tertinggi pada dimensi adaptive fuctioning dan terendah pada dimensi compliance. Anak dari ibu tidak bekerja memiliki perkembangan sosial emosi lebih tinggi daripada anak dengan ibu bekerja. Anak dari status pertumbuhan normal memiliki perkembangan sosial emosi lebih tinggi daripada anak dengan status risiko gangguan pertumbuhan. Hasil lain juga menunjukkan bahwa peningkatan tingkat pendidikan ibu dan kelekatan ibu-anak akan berpengaruh pada peningkatan perkembangan sosial emosi anak usia prasekolah.
\end{abstract}

Kata kunci: kelekatan ibu-anak, pertumbuhan anak, perkembangan sosial emosi anak, anak prasekolah

\section{Mother-child Attachment, Child Growth, and Social-emotional Development of Preschoolers Children}

\begin{abstract}
The research aimed to analyze the influence of mother-child attachment and child growth on social-emotional development of preschoolers children. This research used cross sectional design and conducted in the Village of Balumbang Jaya, West Bogor sub-district, Bogor City.. This research involved 100 families that were selected by purposive sampling and then involved mother as respondent. For answering the purpose of the study, the data were analyzed using multiple linear regression. This research showed that about two of five mothers $(61,0 \%)$ had an insecure mother-child attachment. Moreover, about seven of ten children $(70,0 \%)$ had a risk on growth disorder. Meanwhile, the study revealed that emotional social development of children were in medium categorize with the highest average index on adaptive functioning dimension and the lowest on compliance dimension. Children whose the mother did not work had higher emotional social development than children whose the mother worked. Children who had normal growth status, had higher emotional social development than children who had the risk of growth disorder status. Moreover, increasing of education level of the mother and mother-child attachment will affect the improvement of social-emotional development of preschoolers children.
\end{abstract}

Keywords: mother-child attachment, child's growth, social-emotional development of children, preschool children

\section{Pendahuluan}

Kualitas anak balita saat ini merupakan penentu Sumber Daya Manusia (SDM) di masa yang akan datang. Kualitas anak dapat dilihat dari dua dimensi yaitu pertumbuhan dan perkembangan. Pertumbuhan dan perkembangan mengalami peningkatan yang pesat pada lima tahun pertama kehidupan. Usia prasekolah merupakan salah satu periode emas tumbuh kembang anak. Myers (1992) mendefinisikan pertumbuhan sebagai perubahan secara kuantitatif pada aspek fisik, yaitu merupakan proses pertambahan jumlah dan ukuran sel. Ukuran pertumbuhan anak bisa dilihat dari penambahan berat badan atau tinggi badan atau kedua-duanya. Laporan hasil Stimulasi Deteksi dan Intervensi Tumbuh Kembang (SDITK) balita di Kota Bogor tahun 2014 menunjukkan sebanyak 1.005 balita 
mengalami gangguan pertumbuhan (Dinkes Kota Bogor, 2015). Gangguan pertumbuhan yang terjadi pada anak balita dapat menimbulkan efek negatif jangka panjang pada perkembangan kognitif, prestasi sekolah, perilaku, dan produktivitas kerja di masa dewasa (Dewey \& Begum, 2011).

Sementara itu, Myers (1992) mendefinisikan perkembangan anak sebagai proses perubahan pada anak untuk belajar pada tingkatan yang lebih kompleks dalam berpikir, bergerak, berperasaan dan berhubungan dengan yang lain. Aspek perkembangan anak meliputi perkembangan fisik motorik, kognitif, bahasa, dan sosial emosi. Salah satu perkembangan yang penting pada anak usia prasekolah adalah perkembangan sosial emosi. Anak usia prasekolah merupakan anak usia 3-6 tahun yang mempunyai tanggung jawab besar dalam aktivitas mereka sehari-hari dan menunjukkan tingkat yang lebih matang untuk dapat berinteraksi dengan orang lain. Perkembangan sosial emosi yang tidak tercapai secara optimal dapat menimbulkan masalah sosial emosi pada anak (Kruizinga et al., 2011). Menurut Brauner \& Stephens (2006) sekitar 9,5 hingga 14,2 persen balita yang mengalami keterlambatan perkembangan sosial emosi akan berdampak negatif pada fungsi perkembangan dan kesiapan sekolah mereka. Penelitian Velderman et al. (2010) menemukan bahwa sekitar 8,0 hingga 9,0 persen anak prasekolah mengalami masalah sosial emosi seperti perasaan cemas, depresi, berperilaku tidak taat, kurangnya hubungan dengan teman sebaya, kurangnya keterampilan sosial, dan kinerja akademik yang buruk. Anak yang mengalami keterlambatan perkembangan sosial emosi pada saat usia dini cenderung lebih berisiko untuk berperilaku maladaptif seperti perilaku antisosial, kriminalitas, dan penggunaan narkoba di kemudian hari.

Penelitian lain juga menunjukkan bahwa ada hubungan signifikan antara perkembangan emosi sosial dengan perilaku dan keberhasilan sekolah (Coolahan et al., 2000). Anak-anak tidak bisa belajar membaca jika anak memiliki masalah yang mengalihkan perhatian dari kegiatan belajar, seperti masalah bergaul dengan orang lain, masalah mengendalikan emosi negatif, dan masalah yang mengganggu hubungan dengan teman sebaya, guru, dan orang tua. Howes et al. (1998) menyebutkan bahwa hubungan persahabatan pertama kali dibentuk pada tahun prasekolah. Perolehan keterampilan persahabatan prososial selama usia prasekolah memprediksi kesiapan sekolah dasar dan keberhasilan akademik. Perilaku prososial dapat membina hubungan positif dengan guru dan teman sebaya sehingga memotivasi dan menciptakan perasaan sosial emosi yang aman dan nyaman di dalam kelas yang mendukung eksplorasi dan meningkatkan pembelajaran (Konold \& Pianta, 2005).

Berdasarkan Teori Erikson (1950), perkembangan sosial emosi anak usia prasekolah meliputi dua tahapan penting. Pertama, adalah tahapan autonomy vs shame/doubt atau yang juga dikenal sebagai kemandirian vs malu/ragu. Tahapan ini terjadi ketika anak berada pada usia 2-4 tahun. Pada tahap ini anak memiliki kemampuan untuk dapat mengendalikan diri (self-regulation), dan mulai berkembangnya rasa kepercayaan diri. Oleh karenanya, anak perlu diberikan peluang untuk melakukan sendiri apa saja yang bisa dilakukan tanpa dibantu orang lain sehingga proses pembentukan kemandiriannya dapat berjalan dengan baik. Orang tua sebaiknya tidak terlalu banyak melarang dan memarahi karena dapat membuat anak merasa tidak mampu dan ragu dengan kemampuan dirinya. Akibatnya, rasa percaya diri anak akan sulit untuk tumbuh. Tahapan kedua yaitu initiative vs guilt yang juga disebut sebagai tahap inisiatif vs rasa bersalah yang berlangsung pada usia 4-6 tahun. Pada tahap ini anak aktif bereksperimen, berimajinasi, berani mencoba, berani mengambil risiko, dan senang bergaul dengan temannya. Apabila anak pada masa ini sering dikritik maka emosi yang timbul adalah negatif, merasa apa yang dikerjakan selalu salah sehingga anak cenderung bersikap apatis (kurang antusias), takut salah, dan tidak berani mencoba atau mengambil risiko.

Sementara itu, Squires et al. (2002) membagi perkembangan sosial emosi anak menjadi tujuh dimensi, yaitu: 1) self-regulation (kemampuan anak untuk menenangkan atau menyesuaikan diri dengan kondisi fisiologis, lingkungan dan stimulasi); 2) compliance (kemampuan anak untuk menyesuaikan diri dengan arahan orang lain dan mengikuti aturan); 3) communication (kemampuan anak untuk menanggapi atau memulai sinyal verbal atau non-verbal untuk menunjukkan perasaan, afektif); 4) adaptive functioning (keberhasilan atau kemampuan anak untuk mengatasi kebutuhan fisiologisnya, misalnya: jam tidur, makan dan keselamatan diri); 5) autonomy (kemampuan anak untuk memulai diri atau merespon tanpa bimbingan); 6) affect (kemampuan anak untuk menunjukkan perasaannya sendiri dan empati terhadap 
orang lain); dan 7) interaction with people (kemampuan anak untuk menanggapi atau memulai tanggapan sosial dengan orang tua, orang dewasa lainnya, dan teman).

Pertumbuhan dan perkembangan merupakan dua proses yang berjalan secara simultan. Perkembangan selalu melibatkan proses pertumbuhan sebagai syarat kematangan fungsi yang mengarah pada perkembangan anak. Menurut Bronfenbrenner, seorang anak dalam proses tumbuh kembangnya dipengaruhi pertama kali secara langsung oleh lingkungan keluarganya. Peran ibu sangatlah dominan untuk mengasuh dan mendidik anak balita agar tumbuh dan berkembang menjadi anak yang berkualitas. Menurut Megawangi (2014), kualitas kelekatan ibu-anak berperan penting dalam mengasuh dan mendidik anak. Ainsworth (1989) mengatakan kelekatan adalah ikatan emosional yang dibentuk seorang individu dengan orang lain yang bersifat spesifik dan mengikat dalam suatu kedekatan yang bersifat kekal sepanjang waktu. Penelitian van der Voort et al. (2014) menemukan bahwa anak dengan kelekatan aman (secure attachment) menghadapi situasi sosial yang baru dengan dasar rasa kepercayaan. Sebaliknya, anak dengan kelekatan tidak aman (insecure attachment) cenderung memodelkan dirinya sendiri sebagai pribadi yang tidak kompeten dan pengalaman dengan pengasuh utamanya memengaruhi keyakinan serta harapan anak tentang hubungan di masa depan.

Di Indonesia, penelitian mengenai perkembangan anak sudah banyak dilakukan. Akan tetapi penelitian dengan melihat perkembangan sosial emosi sebagai salah satu aspek perkembangan yang penting dan keterkaitannya dengan pertumbuhan anak serta kelekatan ibu-anak belum banyak dilakukan. Berdasarkan hal tersebut maka penting dilakukan penelitian mengenai pengaruh pertumbuhan dan kelekatan ibuanak terhadap perkembangan sosial emosi anak usia prasekolah. Tujuan dari penelitian ini, adalah 1) mengidentifikasi pertumbuhan anak, kelekatan ibu-anak, dan perkembangan sosial emosi anak usia prasekolah dan 2) menganalisis pengaruh pertumbuhan dan kelekatan ibu-anak terhadap perkembangan sosial emosi anak usia prasekolah.

\section{METODE}

Penelitian ini menggunakan desain cross sectional study.. Lokasi penelitian dipilih secara purposive yaitu Kelurahan Balumbang
Jaya, Kecamatan Bogor Barat, Kota Bogor dipilih dengan pertimbangan berdasarkan prevalensi balita yang mengalami gangguan pertumbuhan tertinggi di Kecamatan Bogor Barat. Penelitian dilakukan pada bulan dari bulan Maret sampai April 2016.

Populasi dalam penelitian ini adalah keluarga yang ada di Kelurahan Balumbang Jaya, Kecamatan Bogor Barat, Kota Bogor yang memiliki anak usia 3-5 tahun. Penentuan contoh dilakukan secara purposive sampling dengan krieria keluarga utuh yang memiliki anak usia 3-5 tahun yang diasuh oleh ibunya sendiri, aktif mengikuti kegiatan penimbangan berat badan balita di Posyandu setiap bulan dalam tiga bulan terakhir sebelum penelitian, dan bersedia diwawancara. Jumlah contoh sebanyak 100 keluarga. Responden penelitian adalah ibu dari keluarga contoh terpilih.

Pengambilan data dilakukan dengan wawancara menggunakan kuesioner. Data primer terdiri atas karakteristik keluarga, karakteristik anak, kelekatan ibu-anak, dan perkembangan sosial emosi anak. Data sekunder diperoleh dari Posyandu berupa data berat badan (BB) anak pada KMS. Kelekatan ibu-anak diukur dengan menggunakan instrumen Attachment Q-Set (AQS) yang dikembangkan oleh Waters (1987) dan dimodifikasi oleh peneliti dengan Cronbach's alpha 0,701 terdiri dari 30 butir pernyataan dengan pilihan jawaban $1=$ tidak pernah, 2=kadang-kadang, 3=sering, dan 4=selalu. Setiap pernyataan diberi jawaban dengan menghasilkan skor maksimal 120 dan minimal 30. Sistem skoring dibuat secara konsisten yaitu semakin tinggi skor maka semakin tinggi pula kategorinya. Selanjutnya, skor diindeks dan dikategorikan menjadi dua yaitu: tidak aman/insecure $(0,0-69,0)$ dan aman/secure $(70,0-100,0)$.

Pertumbuhan anak diukur melalui indeks antropometri yang digunakan untuk menentukan status pertumbuhan anak dengan standar baku nasional di Indonesia yang tertera pada Kartu Menuju Sehat (KMS) dengan cara menilai garis pertumbuhannya atau menghitung kenaikan berat badan anak dengan Kenaikan Berat Badan Minimal (KBM) berdasarkan indeks antropometri berat badan menurut umur (BB/U) yang dibedakan berdasarkan jenis kelamin anak. KMS dibedakan antara KMS anak laki-laki dan KMS anak perempuan. KMS anak laki-laki berwarna dasar biru dan terdapat tulisan untuk laki-laki dan KMS perempuan berwarna dasar merah muda dan terdapat tulisan untuk perempuan. 
Anak ditimbang dengan menggunakan timbangan dacin secara rutin setiap bulan dalam tiga bulan terakhir (Januari-Maret) yang dilakukan oleh petugas kader di Posyandu.

Hasil penimbangan berat badan anak secara rutin setiap bulan dalam tiga bulan terakhir dibandingkan dengan standar baku menurut KMS Kemenkes RI (2010), yaitu 1) status pertumbuhan normal, 2) status risiko gangguan pertumbuhan, 3) status gangguan pertumbuhan.

Status pertumbuhan dapat tergolong normal apabila: 1)grafik berat badan memotong garis pertumbuhan di atasnya, kenaikan berat badan kurang dari sama dengan KBM ( $\geq 200 \mathrm{~g})$ dan berada pada garis pita berwarna hijau; atau 2) grafik berat badan mengikuti garis pertumbuhannya (pita berwarna hijau), dan kenaikan berat badan lebih dari sama dengan KBM ( $\geq 200$ g). Selanjutnya status pertumbuhan anak dapat digolongkan menjadi risiko gangguan pertumbuhan apabila: 1) grafik berat badan memotong garis pertumbuhan di bawahnya, kenaikan berat badan kurang dari KBM (<200g); atau 2) grafik berat badan mendatar, kenaikan berat badan kurang dari KBM (<200 g); atau 3) Grafik berat badan menurun, grafik berat badan kurang dari KBM $(<200 \mathrm{~g})$; atau 4) kenaikan berat badan lebih dari sama dengan KBM ( $\geq 200 \mathrm{~g}$ ), tetapi grafik berat badan berada di luar garis pertumbuhan normal (pita berwarna kuning bagian bawah), atau 5) kenaikan berat badan lebih dari sama dengan KBM $(\geq 200 \mathrm{~g})$, tetapi grafik berat badan berada di luar garis pertumbuhan normal (pita berwarna kuning bagian atas). Sementara itu, status gangguan pertumbuhan cirinya adalah: 1) grafik berat badan berada di bawah garis merah dan 2) grafik berat badan berada di atas pita bewarna kuning bagian atas.

Perkembangan sosial emosi anak diukur dengan menggunakan instrumen yang dimodifikasi dari Ages \& Stages Questionnaires: Social-Emotional (ASQ: SE) yang dikembangkan oleh Squires et al. (2002); yang terdiri dari 30 butir pernyataan dengan Cronbach's alpha yaitu ASQ:SE 36 month/ 3 year (0,825), ASQ: SE 48 month/4 year (0,701), dan ASQ: SE 60 month/ 5 year $(0,870)$. Setiap kuesioner terdiri dari 30 butir pernyataan dengan tujuh dimensi, yaitu: selfregulation, compliance, communication, adaptive functioning, autonomy, affect, dan interaction with people dengan pilihan jawaban $1=$ tidak pernah, $2=$ kadang, $3=$ sering, dan $4=$ selalu. Sistem skoring dibuat secara konsisten yaitu semakin tinggi skor maka semakin tinggi pula kategorinya. Selanjutnya, skor diindeks per dimensi dan dikategorikan menjadi tiga yaitu: rendah $(0,0-59,0)$, sedang $(60,0-80,0)$ dan tinggi $(81,0-100,0)$. Perkembangan sosial emosi anak secara umum diperoleh dari indeks rataan tujuh dimensi perkembangan sosial emosi.

Data yang telah dikategorikan dan diubah dalam bentuk indeks diolah dengan menggunakan program Microsoft Excel dan SPSS for windows. Analisis deskriptif digunakan untuk mengidentifikasi karakteristik keluarga (usia orang tua, lama pendidikan orang tua, status pekerjaan ibu, besar keluarga dan pendapatan keluarga per kapita/bulan), karakteristik anak (usia anak, jenis kelamin, dan status pendidikan anak), kelekatan ibuanak, pertumbuhan anak dan perkembangan sosial emosi anak. Analisis data juga dilakukan dengan uji regresi linear berganda untuk mengetahui pengaruh kelekatan ibu-anak dan pertumbuhan anak terhadap perkembangan sosial emosi anak usia prasekolah. Nilai capaian dari kelekatan ibu-anak dan perkembangan sosial emosi anak diperoleh dari rumus:

$$
\mathrm{Y}=\frac{\mathrm{X} \text { - nilai minimum }}{\text { Nilai maksimum }- \text { nilai minimum }} \times 100
$$

Keterangan:

$Y=$ Skor dalam persen

$X=$ Skor yang diperoleh untuk setiap contoh

\section{HASIL}

\section{Karakteristik Keluarga dan Anak}

Tabel 1 menunjukkan bahwa rata-rata usia ayah yaitu 36,26 tahun atau termasuk kategori dewasa awal, dengan usia termuda adalah 23 tahun dan tertua adalah 53 tahun. Sementara itu, rata-rata usia ibu adalah 31,57 tahun atau berada pada kelompok usia dewasa awal, dengan usia termuda 20 tahun dan usia tertua adalah 46 tahun. Hasil penelitian menunjukkan bahwa lebih dari setengah ayah $(53,0 \%)$ dan sebanyak 39,0 persen ibu telah mencapai pendidikan setingkat SMA dengan rataan lama pendidikan ayah yaitu 10,52 tahun dan ibu 9,54 tahun. Selain itu, lebih dari tiga per empat $(80,0 \%)$ ibu tidak bekerja. Rata-rata jumlah anggota keluarga terdiri dari 5 orang, dengan jumlah paling sedikit 3 orang yang paling banyak 12 orang per keluarga. Rata-rata pendapatan keluarga per kapita/bulan sebesar Rp 471.600,00 dengan pendapatan per kapita/bulan terendah adalah Rp120.000,00 dan terbesar adalah Rp1.500.000,00. 
Tabel 1 Nilai minimum, nilai maksimum, rataan, dan standar deviasi karakteristik keluarga dan anak

\begin{tabular}{|c|c|c|c|}
\hline $\begin{array}{l}\text { Karakteristik } \\
\text { Keluarga }\end{array}$ & Min & Maks & Rataan \pm SD \\
\hline $\begin{array}{l}\text { Usia ayah } \\
\text { (tahun) }\end{array}$ & 23 & 53 & $36,26 \pm 6,88$ \\
\hline Usia ibu (tahun) & 20 & 46 & $31,57 \pm 5,81$ \\
\hline $\begin{array}{l}\text { Lama pendidikan } \\
\text { ayah (tahun) }\end{array}$ & 6 & 16 & $10,52 \pm 2,52$ \\
\hline $\begin{array}{l}\text { Lama pendidikan } \\
\text { ibu (tahun) }\end{array}$ & 4 & 16 & $9,54 \pm 2,71$ \\
\hline $\begin{array}{l}\text { Besar keluarga } \\
\text { (orang) }\end{array}$ & 3 & 12 & $5,49 \pm 2,14$ \\
\hline $\begin{array}{l}\text { Pendapatan } \\
\text { perkapita (Rp } \\
\text { 000/bln) }\end{array}$ & 120 & 1.500 & $471,6 \pm 25.23$ \\
\hline $\begin{array}{l}\text { Usia anak } \\
\text { (bulan) }\end{array}$ & 36 & 60 & $48,51 \pm 6,56$ \\
\hline
\end{tabular}

Selanjutnya, dengan menggunakan cut off Garis Kemiskinan Kota Bogor tahun 2016 yaitu sebesar Rp360.518,00, hasil penelitian menemukan bahwa tiga dari lima keluarga dalam penelitian ini tidak tergolong miskin. Hasil analisis menunjukkan bahwa separuh anak $(50,0 \%)$ berada pada usia 48 hingga 59 bulan dengan rataan usia 48,51 bulan. Selanjutnya, sebagian besar anak (86,0\%) tidak mengikuti pendidikan anak usia dini dengan 59,0 persennya adalah berjenis kelamin laki-laki.

\section{Pertumbuhan Anak}

Penelitian ini menemukan bahwa tujuh dari sepuluh anak (70,0\%) mengalami risiko gangguan pertumbuhan dan sisanya mengalami pertumbuhan normal $(30,0$ (Tabel 2). Hasil tersebut juga mengindikasikan bahwa anak dalam penelitian ini tidak ada yang terkategori sebagai anak yang mengalami gangguan pertumbuhan. Hasil analisis deskriptif menunjukkan bahwa penyebab anak mengalami risiko gangguan pertumbuhan, yaitu: anak lebih suka jajan makanan dan minuman ringan di luar rumah $(94,3 \%)$, anak mengalami sakit $(92,9 \%)$, anak telat makan $(67,1 \%)$, anak kurang nafsu makan $(67,1 \%)$, anak susah makan $(65,7 \%)$, dan anak suka pilih-pilih makanan $(65,7 \%)$.

Tabel 2 Sebaran anak berdasarkan status pertumbuhan

\begin{tabular}{lcc}
\hline $\begin{array}{c}\text { Status Pertumbuhan } \\
\text { Anak }\end{array}$ & $\mathrm{n}$ & $\%$ \\
\hline $\begin{array}{l}\text { Normal } \\
\begin{array}{l}\text { Risiko gangguan } \\
\text { pertumbuhan }\end{array}\end{array}$ & 30 & 30,0 \\
\hline Total & 70 & 70,0 \\
\hline
\end{tabular}

\section{Kelekatan Ibu-Anak}

Tabel 3 menunjukkan bahwa rata-rata indeks kelekatan ibu-anak adalah 67,57. Hasil penelitian menunjukkan bahwa hampir tiga per lima ibu $(61,0 \%)$ memiliki kelekatan ibu-anak terkategori tidak aman (insecure). Hasil analisis deskriptif menunjukkan bahwa ketika anak merasa bosan, anak jarang pergi ke ibunya untuk bermain bersama $(94,0 \%)$, anak jarang mengajak ibu bermain bersama, dan lebih memilih untuk bermain sendiri $(89,0 \%)$. Hasil penelitian juga menemukan anak tidak suka bermain di dekat ibu $(87,0 \%)$. Ketika anak sedang marah atau sedih, anak lebih bisa ditenangkan oleh orang lain dibandingkan dengan ibu $(88,0 \%)$. Selain itu, anak sulit berhenti menangis, meskipun sudah dipeluk oleh ibu (87,0\%). Anak juga tidak mau mengaku salah kepada ibu, ketika dia berperilaku tidak baik $(84,0 \%)$ dan anak tidak mau berbicara dan bermain dengan orang lain, meskipun ibu telah membujuknya $(81,0 \%)$.

Sementara itu, hasil penelitian juga menemukan bahwa sebanyak 39,0\% ibu memiliki kelekatan ibu-anak terkategori aman (secure). Hasil analisis deskriptif menunjukkan bahwa anak merasa gembira dan tertawa saat bercanda bersama ibu $(97,0 \%)$, anak suka memeluk atau mendekap ibu secara spontan $(95,0 \%)$, anak merasa aman dan nyaman bermain apabila ibu berada di dekatnya $(94,0 \%)$, dan juga anak suka berpelukan dan berpegangan tangan dengan ibu $(91,0 \%)$. Selain itu, anak tidak bersembunyi atau menghindari ketika ada orang asing yang datang ke rumah apabila ibu berada di dekatnya $(89,0 \%)$, dan anak suka menyapa ibu dengan senyuman apabila ibunya pulang $(89,0 \%)$. Anak juga tidak menangis ketika ada orang asing yang datang kerumah apabila ibu berada di dekatnya $(88,0 \%)$.

\section{Perkembangan Sosial Emosi Anak}

Tabel 4 menunjukkan bahwa indeks rataan dimensi yang terkategori paling tinggi pada variabel perkembangan sosial emosi anak adalah adaptive functioning $(97,78)$.

Tabel 3 Sebaran ibu berdasarkan kelekatan ibu-anak

\begin{tabular}{lrr}
\hline Kelekatan antara Ibu dan Anak & \multicolumn{1}{c}{$\mathrm{n}$} & $\%$ \\
\hline Tidak aman (insecure) $(<70 \%)$ & 61 & 61,0 \\
Aman (secure) $(\geq 70 \%)$ & 39 & 39,0 \\
Total & 100 & 100,0 \\
\hline Min-maks & $47,00-84,00$ \\
Rata-rata $\pm S D$ (indeks) & $67,57 \pm 6,91$ \\
\hline
\end{tabular}


Tabel 4 Nilai minimum, nilai maksimum, rataan dan standar deviasi perkembangan sosial emosi anak

\begin{tabular}{lrrr}
\hline Dimensi Perkembangan Sosial Emosi & $\begin{array}{c}\text { Minimum } \\
\text { (indeks) }\end{array}$ & $\begin{array}{c}\text { Maksimum } \\
\text { (indeks) }\end{array}$ & \multicolumn{1}{c}{$\begin{array}{c}\text { Rataan } \pm S D \\
\text { (indeks) }\end{array}$} \\
\hline Self-regulation & 27,78 & 100,00 & $68,13 \pm 16,41$ \\
Compliance & 11,11 & 100,00 & $58,36 \pm 18,84$ \\
Communication & 33,33 & 100,00 & $89,78 \pm 13,92$ \\
Adaptive functioning & 66,00 & 100,00 & $97,78 \pm 6,49$ \\
Autonomy & 26,67 & 93,33 & $67,19 \pm 16,42$ \\
Affect & 58,00 & 100,00 & $92,37 \pm 9,71$ \\
Interaction with people & 41,67 & 100,00 & $79,44 \pm 14,57$ \\
Perkembangan sosial emosi total & 57,94 & 91,67 & $79,06 \pm 6,80$ \\
\hline
\end{tabular}

Hasil analisis menunjukkan bahwa anak tidak pernah menyakiti dirinya sendiri untuk tujuan tertentu $(100,0 \%)$, anak tidur setidaknya 8 jam per hari $(99,0 \%)$, dan anak tidak mempunyai masalah makan $(97,0 \%)$. Indeks rataan dimensi yang terkategori paling rendah adalah compliance $(58,36)$, dengan indikatornya adalah anak tidak mau mematuhi perintah ibu $(89,0 \%)$, anak tidak mau mematuhi peraturan di dalam rumah $(87,0 \%)$, dan anak tidak mau mematuhi perintah dari orang dewasa yang dia kenal (85,0\%). Secara keseluruhan, perkembangan sosial emosi anak terkategori sedang dengan indeks rataan 79,06.

\section{Pengaruh Pertumbuhan dan Kelekatan ibu- anak terhadap Perkembangan Sosial Emosi Anak Usia Prasekolah}

Hasil uji regresi linear berganda menemukan bahwa lama pendidikan ibu, status pekerjaan ibu, status pertumbuhan anak, dan kelekatan antara ibu dan anak berpengaruh signifikan terhadap perkembangan sosial emosi anak usia prasekolah dilihat dari $\mathrm{F}$ hitung sebesar
2,413. Model uji analisis regresi linier berganda pada Tabel 5 menghasilkan nilai Adjusted $R$ Square sebesar 0,102. Hal ini berarti bahwa sebesar 10,2 persen faktor-faktor yang berpengaruh terhadap perkembangan sosial emosi anak dapat dijelaskan oleh model dan sisanya 89,8 persen dijelaskan oleh variabel lain yang tidak diteliti dalam penelitian ini. Penelitian ini menunjukkan bahwa lama pendidikan ibu, status pekerjaan ibu, status pertumbuhan anak, dan kelekatan antara ibuanak berpengaruh signifikan terhadap perkembangan sosial emosi anak. Selain itu, lama pendidikan ibu berpengaruh positif dan signifikan terhadap perkembangan sosial emosi anak $(\beta=0,558)$. Artinya, setiap kenaikan 1 tahun tingkat pendidikan ibu akan menaikkan skor perkembangan sosial emosi anak sebesar 0,558. Hasil penelitian juga menemukan bahwa status pekerjaan ibu berpengaruh negatif dan signifikan terhadap perkembangan sosial emosi anak. Hal ini artinya anak dengan ibu tidak bekerja akan memiliki perkembangan sosial emosi lebih tinggi daripada anak dengan ibu bekerja.

Tabel 5 Koefisien regresi pertumbuhan dan kelekatan ibu-anak terhadap perkembangan sosial emosi anak

\begin{tabular}{|c|c|c|c|}
\hline Variabel & $\begin{array}{c}\text { Tidak } \\
\text { terstandarisasi }(\beta)\end{array}$ & $\begin{array}{c}\text { Terstandarisasi } \\
(\beta)\end{array}$ & Sig. \\
\hline Konstanta & 50,300 & - & $0,000^{\star \star *}$ \\
\hline Lama pendidikan ibu & 0,558 & 0,222 & $0,028^{* *}$ \\
\hline Status pekerjaan ibu ( $0=$ tidak bekerja, $1=$ bekerja $)$ & $-3,652$ & $-0,216$ & $0,037^{\star *}$ \\
\hline Besar keluarga (orang) & $-0,020$ & $-0,006$ & 0,950 \\
\hline Usia anak (tahun) & 0,151 & 0,152 & 0,170 \\
\hline Jenis kelamin anak (0 laki-laki, $1=$ perempuan) & 1,285 & 1,345 & 0,956 \\
\hline $\begin{array}{l}\text { Status pendidikan anak }(0=\text { tidak mengikuti PAUD, } \\
1=\text { mengikuti PAUD) }\end{array}$ & $-3,579$ & 2,186 & 0,105 \\
\hline $\begin{array}{l}\text { Status pertumbuhan anak ( } 0=\text { risiko gangguan } \\
\text { pertumbuhan, } 1=\text { normal) }\end{array}$ & 2,130 & 0,164 & $0,099^{*}$ \\
\hline Kelekatan antara ibu-anak (indeks) & 0,179 & 0,182 & $0,065^{*}$ \\
\hline $\mathrm{R}^{2}$ & \multicolumn{3}{|c|}{0,418} \\
\hline Adjusted R Square & \multicolumn{3}{|c|}{0,102} \\
\hline $\mathrm{F}$ & \multicolumn{3}{|c|}{2,413} \\
\hline 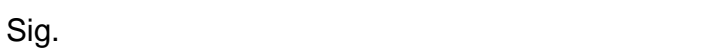 & \multicolumn{3}{|c|}{$0,021^{* *}$} \\
\hline
\end{tabular}


Variabel pertumbuhan anak juga berpengaruh positif signifikan terhadap perkembangan sosial emosi anak. Hasil tersebut artinya anak dengan status pertumbuhan normal akan memiliki perkembangan sosial emosi lebih tinggi daripada anak dengan status risiko gangguan pertumbuhan. Selanjutnya, hasil penelitian juga menemukan bahwa kelekatan ibu-anak berpengaruh positif signifikan terhadap perkembangan sosial emosi anak $(\beta=0,179)$. Hal tersebut berarti setiap kenaikan 1 skor kelekatan ibu-anak akan menaikkan skor perkembangan sosial emosi anak sebesar 0,179 . Sementara itu, variabel lainnya yang tidak berpengaruh signifikan dalam model yang disusun terhadap perkembangan sosial emosi anak adalah besar keluarga, usia anak, jenis kelamin anak, dan status pendidikan anak.

\section{PEMBAHASAN}

Hasil penelitian ini menemukan bahwa perkembangan sosial emosi anak dipengaruhi secara signifikan oleh kelekatan ibu-anak, pertumbuhan anak, lama pendidikan ibu, dan status pekerjaan ibu. Kelekatan ibu-anak berpengaruh positif signifikan terhadap perkembangan sosial emosi anak. Hasil penelitian ini menguatkan penelitian sebelumnya yang dilakukan oleh Kochanska et al. (2008); van der Voort et al. (2014); dan juga Verissimo et al. (2014) yang menemukan bahwa kelekatan ibu-anak yang aman (secure) berpengaruh positif terhadap perkembangan sosial emosi anak. Anak-anak dengan kelekatan aman (secure attachment) lebih terlibat secara sosial dan lebih menunjukkan keterampilan sosial, emosional dan kognitif yang berkontribusi terhadap penerimaan rekan/teman.

Kelekatan adalah ikatan emosional yang dibentuk seorang individu dengan orang lain yang bersifat spesifik dan mengikat dalam suatu kedekatan yang bersifat kekal sepanjang waktu (Ainsworth, 1989). Ikatan kelekatan (attachment) memiliki beberapa elemen yaitu: 1) ikatan tersebut adalah hubungan emosi dengan seseorang yang spesial; 2) hubungan tersebut menimbulkan rasa aman, nyaman, dan kesenangan; 3) ketiadaan ikatan akan menimbulkan perasaan kehilangan atau meningkatkan penyesalan, kekecewaan. Artinya, derajat ikatan emosi tersebut dapat dilihat atau diukur dari bagaimana hubungan emosinya; terkait dengan rasa aman, nyaman bila berada di dekatnya, serta seberapa perasaan stres, rasa kehilangan, dan penyesalan bila tidak berada di dekatnya.
Kapasitas dan keinginan untuk menciptakan hubungan emosional berhubungan dengan organisasi dan fungsi susunan saraf pada otak manusia. Hal ini hampir sama dengan bagaimana cara otak untuk melihat, mencium, berpikir, berbicara, dan bergerak; demikian pulalah cara manusia untuk mencintai. Sistem saraf otak manusia memungkinkan kita untuk membentuk dan memelihara hubungan emosi yang terbangun selama masa bayi dan tahun pertama kehidupannya. Dengan demikian, pengalaman pada periode pertama kehidupan manusia ini adalah masa yang paling kritis dalam menentukan kapasitas hubungan emosi yang intim dan sehat pada masa selanjutnya. Pembentukan rasa empati, kasih sayang, saling berbagi, penekanan agresi, mencintai, dan berbagai karakter yang menunjukkan individu sehat, bahagia, dan produktif sangat berhubungan dengan kapasitas kelekatan (attachment) yang terbentuk pada saat bayi dan awal masa kanak-kanak. Megawangi (2014) menyatakan bahwa anak dengan kelekatan tidak aman (insecure attachment) akan sulit mengatur emosinya sehingga apabila ada larangan atau keinginan yang tidak terpenuhi, anak akan merengek, menangis meraung-raung, berguling-guling, atau bahkan mengamuk (temper tantrum). Sebaliknya, anak dengan secure attachment akan memiliki kemampuan untuk mengatur emosi. Hal ini akan membawa pengaruh positif dalam proses perkembangan sosial emosi anak. Oleh karena itu, kelekatan ibu tidak hanya menularkan kehangatan secara fisik namun juga kognitif dan afektif yang dirasakan bersama.

Berdasarkan kualitas hubungan anak dengan pengasuh maka anak akan mengembangkan konstruksi mental atau internal working model mengenai diri dan orang lain yang akan menjadi mekanisme penilaian terhadap lingkungan. Perkembangan otak dan proses belajar pada dasarnya adalah proses pembentukan, penguatan, dan pemangkasan koneksi-koneksi dalam otak, dan semua proses ini tergantung pada bagaimana lingkungan membentuknya, terutama pada periode 3 tahun pertama kehidupan anak. Pengalaman yang paling sering didapatkan oleh anak akan menjadi koridor informasi yang menetap, sedangkan yang jarang terjadi akan mengalami proses pemangkasan (pruning). Artinya, apabila seorang anak sering mendapatkan perasaan negatif karena ibu yang tidak responsif, sering marah, atau memukul; maka pengalaman tersebut akan tersimpan dalam koridor informasi yang akan membuatnya selalu dalam modus waspada 
dan marah. Sebaliknya, apabila seorang anak dibesarkan dalam lingkungan yang penuh kasih sayang; maka koridor informasi ini akan menetap yang dapat membuatnya penuh kasih sayang. Inilah yang disebut dengan internal working model yang merupakan respon yang sudah terprogram terhadap setiap kejadian atau stimuli yang diperoleh seseorang sebagai mekanisme penilaian terhadap lingkungan (Wong et al., 2011; Megawangi 2014).

Kelekatan ibu-anak mendukung kualitas adaptasi sosial dalam kelompok teman sebaya pada anak usia dini. Kelekatan ibu-anak menyediakan fondasi yang positif dan menjadi faktor yang berpengaruh terhadap perkembangan sosialisasi anak (Kochanska et al., 2009; Kochanska \& Kim 2012). Anak yang merasa yakin terhadap penerimaan lingkungan akan mengembangkan kelekatan yang aman dengan figur lekatnya (secure attachment) dan mengembangkan rasa percaya tidak saja pada ibu namun juga pada lingkungan. Usia dini adalah masa kritis bagi anak untuk menumbuhkan rasa percaya (trust). Jika rasa percaya ini gagal tumbuh pada masa ini maka yang terbentuk pada diri anak adalah rasa tidak percaya (mistrust). Rasa percaya ini adalah fondasi bagi perkembangan sosial emosi yang sehat pada tahap selanjutnya. Rasa percaya ini akan tumbuh apabila lingkungan pengasuhan dapat diprediksi oleh anak. Maksud dari dapat diprediksi anak adalah figur pengasuh harus stabil yang menimbulkan rasa aman dan nyaman, dan juga anak merasa diterima dan disayang. Oleh karena itu, anak memerlukan figur ibu atau pengasuh utama untuk menjalin bonding yang kuat. Siklus kelekatan aman adalah adanya figur kelekatan sebagai basis untuk anak dapat semangat bereksplorasi.

Apabila siklus kelekatan dikaitkan dengan teori Erikson (1950), kebebasan bereksplorasi penting untuk mengembangkan rasa kemandirian anak (autonomy), yaitu perasaan bahwa diri anak mampu mengambil keputusan dan merasa dirinya didukung/dihargai oleh ibunya. Sebaliknya, apabila kelekatan tidak kuat, siklus kelekatan menjadi terbatas. Pada usia dini anak perlu bereksplorasi. Namun, karena interaksi ibu-anak lebih banyak berupa konflik (ibu tidak sabar, pemarah, banyak melarang, anak tidak mudah diatur, dan pembangkang), akan mengakibatkan dampak negatif pada perkembangan kepribadian anak selanjutnya. Interaksi negatif ini diwarnai oleh rasa kekhawatiran akan adanya kritikan/kemarahan sehingga anak merasa ragu dengan kemampuan dirinya (Megawangi
2014). Menurut Erikson (1950) kegagalan dalam mengembangkan aspek psikososial anak pada setiap tahapannya, mengakibatkan sifat-sifat negatif yang terbentuk bisa berdampak negatif pada proses perkembangan selanjutnya. Artinya, kegagalan-kegagalan perkembangan di tahapan awal terbawa sampai dewasa. Hal ini sejalan dengan teori kelekatan yang menganggap begitu pentingnya seorang anak memiliki kelekatan aman karena dianggap sebagai faktor penentu untuk tumbuhnya pribadi yang sehat.

Penelitian ini menemukan bahwa status pertumbuhan anak berpengaruh positif signifikan terhadap perkembangan sosial emosi anak. Hasil penelitian ini mendukung penelitian sebelumnya (Gardner et al., 1999; Chang et al., 2002; Walker et al., 2007; Walker et al., 2011) yang menemukan bahwa anak dengan gangguan pertumbuhan lebih berisiko mengalami masalah sosial emosi yaitu rendahnya aktivitas anak untuk melakukan eksplorasi lingkungan, cenderung tidak ingin bermain dengan teman sebaya (menarik diri dari lingkungan), anak menjadi rewel dan menangis berlebihan dibandingkan anak dengan pertumbuhan normal. Fernald \& Grantham-McGregir (1998) menunjukkan bahwa anak usia prasekolah yang mengalami risiko gangguan pertumbuhan cenderung tidak aktif mengeksplorasi lingkungan dan mengalami perasaan depresi. Anak yang mengalami gangguan pertumbuhan memiliki self-estem yang rendah, peningkatan perilaku agresif, dan menunjukkan masalah sosial emosi yang berpengaruh terhadap penurunan prestasi sekolah (Dewey \& Begum 2001; Gandhi et al., 2011). Selain itu, gangguan pertumbuhan juga menyebabkan anak mengalami sulit tidur karena kebutuhan tubuh mereka tidak tercukupi (intake enegi inadekuat) sehingga anak menjadi rewel.

Pertumbuhan dan perkembangan merupakan proses yang terjadi pada setiap makhluk hidup. Pada manusia, terutama dalam masa kanakkanak, proses tumbuh kembang ini terjadi dengan cepat (Latifah et al., 2010). Perkembangan anak tergantung pada kematangan anak. Kematangan tubuh dan otak merupakan kesiapan untuk menguasai berbagai kemampuan baru pada anak. Anak usia dini merupakan anak yang sedang dalam masa tumbuh kembang karena pada masa ini terjadi pertumbuhan dasar yang akan memengaruhi perkembangan anak di masa selanjutnya. Pertumbuhan anak yang normal akan menunjang perkembangan anak menjadi 
lebih optimal. Kegagalan pertumbuhan dan perkembangan di masa balita dapat berpengaruh terhadap kehidupannya di masa dewasa.

Penelitian ini juga menghasilkan temuan bahwasanya lama pendidikan ibu berpengaruh positif signifikan terhadap perkembangan sosial emosi anak. Hasil penelitian ini mendukung penelitian sebelumnya yang dilakukan oleh Wang et al. (2008) yang menemukan bahwa semakin tinggi tingkat pendidikan ibu akan semakin baik perkembangan anak. Pendidikan berhubungan dengan tingkat pengetahuan seseorang. Pendidikan yang dijalani seseorang memiliki pengaruh pada peningkatan kemampuan berpikir. Dengan kata lain, seseorang yang berpendidikan lebih tinggi akan dapat mengambil keputusan yang lebih rasional, umumnya terbuka untuk menerima perubahan atau hal baru dibandingkan seseorang yang berpendidikan lebih rendah. Oleh karenanya, semakin tinggi tingkat pendidikan orang tua diharapkan pengetahuan tentang perkembangan anak semakin baik sehingga dapat memberikan stimulasi baik fisik, sosial emosi, maupun psikologis yang cukup bagi anak-anaknya.

Pengetahuan orang tua yang terbatas dapat menyebabkan anak kurang atau bahkan tidak menerima stimulasi perkembangan yang cukup dan sesuai dengan tahapan usianya. Kurangnya pengetahuan tentang stimulasi akan berdampak pada sikap yang tidak mendukung terhadap pemberian stimulasi pada anak. Ibu dengan pengetahuan tinggi tentang perkembangan anak cenderung bersikap mendukung terhadap pemberian stimulasi pada anaknya guna perkembangan anak yang optimal. Sebaliknya, ibu dengan pengetahuan yang kurang tentang perkembangan anak cenderung bersikap kurang mendukung dalam pemberian stimulasi perkembangan pada anak. Selain itu, semakin tinggi tingkat pendidikan ibu juga terkait dengan perbaikan aspek kualitas lingkungan rumah bagi anak, terutama respon ibu dalam penyediaan bahan pembelajaran yang menunjang perkembangan anak. Tingkat pendidikan seseorang memengaruhi nilai-nilai yang dianutnya, cara berpikir, cara pandang bahkan persepsinya terhadap suatu masalah (Davis-Kean, 2005).

Temuan lain dalam penelitian ini adalah adanya pengaruh status pekerjaan ibu terhadap perkembangan sosial emosi anak secara negatif signifikan. Hasil penelitian ini sejalan dengan penelitian Nezhad (2013) dan Ering et al. (2014) yang menemukan bahwa investasi waktu dari ibu tidak bekerja dalam keterlibatannya dengan anak berpengaruh positif terhadap perkembangan sosial emosi anak. Pada anak usia dini, teori perkembangan menekankan bahwa waktu yang dihabiskan dengan pengasuh yang konsisten dan responsif diperlukan untuk anak dalam membangun kelekatan aman/ secure attachment (Belsky \& David, 1991). Anak-anak yang menghabiskan waktu dengan orang tua mereka akan membentuk ikatan emosional yang penting sebagai fondasi keterampilan sosial dan emosional mereka (Conger et al., 2002). Sementara itu, permasalahan yang dimiliki ibu bekerja adalah berkurangnya waktu untuk mengasuh anak. Orang tua, terutama ibu bekerja, memiliki peran ganda yang sering kali dihadapkan pada konflik antara kepentingan pekerjaan dan keberadaannya dalam keluarga. Tuntutan pekerjaan yang tinggi dan menyita waktu sering kali menghambat pemenuhan kebutuhan untuk kebersamaan dalam keluarga, merawat, dan mengasuh anak sehingga apabila seorang ibu memiliki pengetahuan tentang perkembangan yang baik, namun ibu terlalu sibuk dengan pekerjaannya mengakibatkan pengetahuan tentang pemberian stimulasi perkembangan pada anak yang diberikan tidak akan optimal. Ibu bekerja merasa terlalu terbebani dalam menyeimbangkan pekerjaan dan keluarga. Apabila ibu membawa stres pekerjaan ke dalam rumah maka anak-anak bisa mengembangkan perilaku negatif.

Ibu bekerja harus membagi waktu antara pekerjaan di luar rumah (sektor publik) dan harus membagi waktu antara pekerjaan di luar rumah (sektor domestik). Adanya dua peran tersebut dapat menyebabkan ibu kesulitan membagi tugas. Pada beberapa kasus, ibu merasakan kelelahan luar biasa begitu tiba di rumah sehingga kesempatan untuk menggendong atau bermain dan bercengkrama dengan anak menjadi terbatas. Dilema antara menjadi wanita karier dan menjadi ibu yang baik kemungkinan akan menimpa wanita bekerja. Lemahnya dukungan dari suami juga akan semakin menyulitkan ibu dalam mengasuh anak dan memberikan emosi positif saat berinteraksi dengan anak. Beban kerja di luar rumah, stres dunia kerja, serta stres kehidupan perkawinan karena tidak adanya dukungan suami adalah faktor yang diduga kuat mempengaruhi kualitas pengasuhan ibu kepada anaknya. Bahkan keharmonisan pasangan suami-istri juga berhubungan dengan kualitas pengasuhan 
yang berlangsung dalam keluarga tersebut. Keluarga yang tidak harmonis cenderung memberikan pengasuhan yang relatif tidak kondusif pada tumbuh kembang anak (Geoffrey et al., 2011; Nezhad, 2013).

\section{SIMPULAN DAN SARAN}

Berdasarkan karakteristik keluarga yang dinilai, ditemukan bahwa keluarga dalam penelitian ini memiliki karakteristik sebagian besar ibu memiliki lama pendidikan ibu setingkat SMA, empat dari lima $(80,0 \%)$ ibu tidak bekerja, rataan pendapatan perkapita $\mathrm{Rp}$ $471.600,00$, dan tiga dari lima $(60,0 \%)$ keluarga terkategori tidak miskin. Karakteristik anak dalam penelitian ini adalah proporsi anak laki-laki lebih banyak, rataan usia anak 48,51 bulan, dan hampir sembilan dari 10 (86,0\%) anak tidak mengikuti PAUD.

Penelitian ini menemukan bahwa hampir tujuh dari sepuluh $(70,0 \%)$ anak mengalami risiko gangguan pertumbuhan. Selain itu, sekitar tiga dari lima $(61,0 \%)$ ibu memiliki tidak aman (insecure) dengan anaknya. Perkembangan sosial emosi anak secara umum terkategori sedang dengan indeks rataan 79,06 $\pm 6,80$, yang mana rataan tertinggi pada dimensi adaptive fuctioning $(97,78 \pm 6,49)$ dan terendah pada dimensi compliance $(58,36 \pm 18,84)$. Hasil uji regresi linier bergadan menunjukkan bahwa peningkatan tingkat pendidikan ibu dan kelekatan ibu-anak akan berpengaruh terhadap peningkatan perkembangan sosial emosi anak. Anak dengan status pertumbuhan normal dan ibu yang tidak bekerja akan memiliki perkembangan sosial emosi yang lebih tinggi.

Berdasarkan hasil penelitian, yang menunjukkan pengaruh positif dari kelekatan ibu-anak terhadap perkembangan sosial emosi anak usia prasekolah, maka disarankan bagi Dinas Kesehatan (Dinkes) Kota Bogor dan Puskesmas Sindang Barang, melalui media massa diharapkan lebih meningkatkan sosialisasi tentang pengasuhan, kelekatan ibuanak, dan tumbuh kembang anak. Hal tersebut dikarenakan pada penelitian ini memperkuat temuan bahwa kelekatan ibu-anak yang aman (secure attachment) dapat meningkatkan perkembangan sosial emosi anak. Selain itu, bagi para ibu dengan anak usia prasekolah di Kelurahan Balumbang Jaya, perlu diberikan sosialisasi dan pelatihan mengenai pola asuh makan dan juga makanan bergizi serta aman bagi anak. Hal tersebut dikarenakan anak yang memiliki status pertumbuhan normal terbukti memiliki perkembangan sosial emosi yang lebih tinggi daripada anak dengan risiko gangguan pertumbuhan. Bagi para ibu yang bekerja, diharapkan masih dapat memberikan waktu dan perhatian untuk mengasuh anak dan menyediakan quality time untuk berinteraksi dengan anak dalam melakukan kegiatan-kegiatan yang bermanfaat bagi pengoptimalan pertumbuhan dan perkembangannya. Hal tersebut dikarenakan pada penelitian ini ditemukan bahwa anak dari ibu tidak bekerja memiliki perkembangan sosial emosi yang lebih tinggi daripada anak dari ibu bekerja. Selain itu, diharapkan juga untuk Posyandu di Kelurahan Balumbang Jaya dapat bekerjasama dengan masyarakat untuk melaksanakan kegiatan sosialisasi dan pelatihan dalam rangka meningkatkan pengetahuan serta keterampilan para ibu.

\section{DAFTAR PUSTAKA}

Ainsworth, M. S. (1989). Attachments beyond infancy. American Psychologist, 44(4), 709-716.

Belsky J, \& David E. (1991). Early and extensive maternal employment and young children's socioemotional development: Children of the National Longitudinal Survey of Youth. Journal of Marriage and the Family. 53(4), 10831098.

Brauner, C. B., \& Stephens, C. B. (2006). Estimating the prevalence of early childhood serious emotional/behavioral disorders: challenges and recommendations. Public Health Reports, 303-310.

Chang, S. M., Walker, S. P., GranthamMcGregor, S., \& Powell, C. A. (2002). Early childhood stunting and later behaviour and school achievement. Journal of Child Psychology and Psychiatry, 43(6), 775-783.

Conger, R. D., Wallace, L. E., Sun, Y., Simons, R. L., McLoyd, V. C., \& Brody, G. H. (2002). Economic pressure in African American families: a replication and extension of the family stress model. Developmental psychology, 38(2), 179193.

Coolahan, K., Fantuzzo, J., Mendez, J., \& McDermott, P. (2000). Preschool peer interactions and readiness to learn: Relationships between classroom peer play and learning behaviors and conduct. Journal of Educational Psychology, 92(3), 458-465. 
Davis-Kean, P. E. (2005). The influence of parent education and family income on child achievement: the indirect role of parental expectations and the home environment. Journal of Family Psychology, 19(2), 294-304.

Dewey, K. G., \& Begum, K. (2011). Long-term consequences of stunting in early life. Maternal \& Child Nutrition, 7(3), 5-18.

[Dinkes] Dinas Kesehatan Kota Bogor. (2015). Stimulasi deteksi dini dan intervensi tumbuh kembang anak (SDDITK) tahun 2014. Bogor: Dinkes.

Ering, S. O., Akpan, F. U., \& Emma-Echiegu, N. (2014). Mothers Employment Demands and Child Development: An Empirical Analysis of Working Mothers in Calabar Municipality. American International Journal of Contemporary Research, 4(4). 184-191.

Erikson E. (1950). Childhood and Society. New York :W.W Norton \& Company, Inc.

Fernald, L. C., \& Grantham-McGregor, S. M. (1998). Stress response in school-age children who have been growth retarded since early childhood. The American Journal of Clinical Nutrition, 68(3), 691698.

Gandhi, M., Ashorn, P., Maleta, K., Teivaanmäki, T., Duan, X., \& Cheung, Y. B. (2011). Height gain during early childhood is an important predictor of schooling and mathematics ability outcomes. Acta Paediatrica, 100(8), 1113-1118.

Gardner, J. M. M., Grantham-McGregor, S. M., Himes, J., \& Chang, S. (1999). Behaviour and development of stunted and nonstunted Jamaican children. Journal of Child Psychology and Psychiatry, 40(05), 819-827.

Geoffrey, L. Brown; Brent A. Mcbride, Kelly K. Bost. (2011). Parental involvement, child temperament, and parents' work hours. Journal of Applied Developmental Psychology, 32(6), 313-322.

Howes, C., Hamilton, C. E., \& Philipsen, L. C. (1998). Stability and continuity of childcaregiver and child-peer relationships. Child Development, 69(2), 418-426.

[KEMENKES RI] Kementerian Kesehatan Republik Indonesia. (2010). Penggunaan Kartu Menuju Sehat (KMS) bagi balita. Jakarta: Kemenkes RI.
Kochanska, G., Barry, R. A., Aksan, N., \& Boldt, L. J. (2008). A developmental model of maternal and child contributions to disruptive conduct: The first six years. Journal of Child Psychology and Psychiatry, 49(11), 1220-1227.

Kochanska, G., Barry, R. A., Stellern, S. A., \& O'bleness, J. J. (2009). Early attachment organization moderates the parent-child mutually coercive pathway to children's antisocial conduct. Child development, 80(4), 1288-1300.

Kochanska, G., \& Kim, S. (2012). Toward a new understanding of legacy of early attachments for future antisocial trajectories: Evidence from two longitudinal studies. Development and psychopathology, 24(03), 783-806.

Konold, T. R., \& Pianta, R. C. (2005). Empirically-derived, person-oriented patterns of school readiness in typicallydeveloping children: Description and prediction to first-grade achievement. Applied Developmental Science, 9(4), 174-187.

Kruizinga, I., Jansen, W., Carter, A. S., \& Raat, H. (2011). Evaluation of an early detection tool for social-emotional and behavioral problems in toddlers: the brief infant toddler social and emotional Assessment-A cluster randomized trial. BMC Public Health, 11(1), 1-6.

Latifah, E., Hastuti, D., \& Latifah, M. (2010). Pengaruh pemberian ASI dan stimulasi psikososial terhadap perkembangan sosial-emosi anak balita pada keluarga ibu bekerja an tidak bekerja. Jurnal IImu Keluarga dan Konsumen, 3(1), 35-45.

Myers R. 1992. The Twelve Who Survive : Strenght: Thening Programs of Early Childhood Development in The Thirld World. Michigan: High/Scope Press.

Megawangi R. (2014). Kelekatan Ibu-Anak "Kunci Membangun Bangsa". Depok: Indonesia Heritage Foundation (IHF).

Nezhad, Z. S. (2013). Analysis of Mothers Employment and its influence on children's' Training in Family", Current Research Journal of Biological Sciences, 5(1), 5-12.

Squires, J., Bricker, D., \& Twombly, E. (2002). Ages \& Stages Questionnaires: SocialEmotional. Paul H. Brookes Publishing Company. 
Van Der Voort, A., Juffer, F., \& J. BakermansKranenburg, M. (2014). Sensitive parenting is the foundation for secure attachment relationships and positive social-emotional development of children. Journal of Children's Services, 9(2), 165-176.

Velderman, M. K., Crone, M. R., Wiefferink, C. H., \& Reijneveld, S. A. (2010). Identification and management of psychosocial problems among toddlers by preventive child health care professionals. The European Journal of Public Health, 20(3), 332-338.

Verissimo, M., Santos, A. J., Fernandes, C., Shin, N., \& Vaughn, B. E. (2014). Associations between attachment security and social competence in preschool children. Merrill-Palmer Quarterly, 60(1), 80-99.

Walker, S. P., Chang, S. M., Powell, C. A., Simonoff, E., \& Grantham-McGregor, S. M. (2007). Early childhood stunting is associated with poor psychological functioning in late adolescence and effects are reduced by psychosocial stimulation. The Journal of Nutrition, 137(11), 2464-2469.

Walker, S. P., Chang, S. M., Vera-Hernández, M., \& Grantham-McGregor, S. (2011). Early childhood stimulation benefits adult competence and reduces violent behavior. Pediatrics, 127(5), 849-857.

Wang, L. W., Wang, S. T., \& Huang, C. C. (2008). Preterm infants of educated mothers have better outcome. Acta Paediatrica, 97(5), 568-573.

Waters E. (1987). Attachment Q-set (Version 3). Diunduh dari http://www.johnbowlby.com. (11 Oktober 2015).

Wong, M., Bost, K. K., Shin, N., Veríssomo, M., Maia, J., Monteiro, L., \& Vaughn, B. E. (2011). Preschool children's mental representations of attachment: Antecedents in their secure base behaviors and maternal attachment scripts. Attachment \& Human Development, 13(5), 489-502. 